\title{
Victims, villains and the rare hero: Analysis of migrant and refugee health portrayals in the Indian print media
}

\author{
EKATHA ANN JOHN, ANUJ KAPILASHRAMI
}

\begin{abstract}
The Indian media's reportage of the Covid-19 pandemic has exposed the State's long-standing apathy towards low-income migrants and the structural neglect and violence faced by them in society. But how consistent were the country's print media in reporting on this population group before the crisis? This paper reports the findings of a study that examines the representation of migrants and refugees and their health in the Indian print media prior to the pandemic. A secondary objective was to examine any variations in their representation based on their social positions (for example, ethnicity, nationality, gender, religion). Using frame and content analyses, three English language newspapers were examined for the period January 1 , 2017 to December 31, 2018. A total of 1,111 articles were retrieved. Analysis revealed that migrants were most frequently framed as "villains", posing a threat to the security, culture, health and economy in their destination states/cities, and less often as victims. On health coverage, the study found that the media frequently pathologised migrants and projected them as carriers of infection. Migrants' religion, ethnicity and class, and their proximity to the majoritarian population appeared most prominent in determining the frame imposed. The articles mostly relied on accounts of state officials and political leaders, whereas migrants' voices comprised less than a quarter of the sources of information. The media thus play a vital role in crystallising these disparities and, through acts of both omission and commission, end up vilifying migrants.
\end{abstract}

Keywords: migrants' health, media representation, frame analysis, intersectionality, Covid-19

\section{Introduction}

Migration and displacement, propelled by growing demographic disparities, socio-economic imbalances, environmental changes, development projects and conflicts,

Authors: Ekatha Ann John, (ekatha.ann@gmail.com), Researcher and Regional Co-coordinator, Migration Health South Asia Network; Anuj Kapilashrami, (corresponding author - a.kapilashrami@essex.ac.uk), Professor, School of Health and Social Care, University of Essex, Essex, UK, and Founding Chair, Migration Health South Asia Network.

To cite: John EA, Kapilashrami A. Victims, villains and the rare hero: Analysis of migrant and refugee health portrayals in the Indian print media. Indian J Med Ethics. 2021 Apr-Jun; 6(2) NS: 145-155. DOI: 10.20529/IJME.2020.131.

Published online first on December 23, 2020.

Manuscript editor: Sandhya Srinivasan

Peer Reviewers: Usha Raman, Santosh Vijaykumar

(C) Indian Journal of Medical Ethics 2020 have been a defining feature of Indian history and society.

According to the Indian Economic Survey, 2017 (1), an average of 9 million people migrated annually between states from 2011 to 2016, mostly for work; a 45\% increase from the annual average of the previous decade. Internal migration in India can be categorised into four types long-term, temporary, circular (repetitive movement between home and host areas, typically for the purpose of employment) and seasonal - that offer important livelihood strategies for the socio-economically weakest sections in rural India (2). Most of these migrants hail from economically backward districts in Uttar Pradesh, Bihar, West Bengal, Assam and Jharkhand (1) and are concentrated in the informal economy, engaging in low-paying, hazardous jobs. Working in unsafe environments for long hours and low wages, they have poor access to services like water, healthcare, sanitation and education, and bear a high burden of discrimination $(2,3)$. India also accounts for $2.5 \%$ of all international migrants or immigrants (4). Although exact figures are unknown, India's Census (2011) (5) estimates there are approximately 3 million immigrants from Bangladesh alone in India, representing $60 \%$ of total immigrants in the country. Illegality of migratory movement in the Indian context is complex in light of the colonial and partition histories in the South Asian region, the ethnic ties immigrants share with the local population, and the challenges of documentation, as evidenced in the case of Assam.

Contemporary political developments in India have made migration a highly politicised issue. In 2015, the Supreme Court of India directed Assam, which shares a border with Bangladesh, to update its National Register of Citizens by requiring people to produce documents of ancestry in order to be enlisted as Indian citizens. The final list of "citizens", published on August 31, 2019, excluded nearly 19 lakh residents of Assam, many of whom belong to economically vulnerable sections with no documents to prove their nativity (6). Termed as a draconian measure targeting Muslim immigrants from Bangladesh, the process resulted in the exclusion of an equal number of Bengali Hindus and Muslims (6). In 2016, the Bharatiya Janata Party(BJP)-led government pushed the Citizenship (Amendment) Bill, which seeks to provide citizenship to select minorities from Bangladesh, Afghanistan and Pakistan who identify themselves as Hindu, Sikh, Buddhist, Jain, Parsi or Christian, but excludes Muslims. Passed in December 2019, the controversial bill together with the NRC process serves as the political backdrop for this study and was the latest trigger for the media's interest in migrants and migration.

Discriminatory anti-immigration policies of the Government 
of India are also reflected in its treatment of Rohingya refugees, a Muslim ethnic minority group from Myanmar (7). As on January 2019, around 18,000 Rohingya refugees and asylum-seekers were registered with the United Nations High Commissioner for Refugees (UNHCR) in India, although the government estimates there are about 40,000 of them in the country (8). In 2017, the Indian government ordered all its states to identify and deport Rohingyas, emphasising their potential to "getting recruited by terrorist organisations" (9). It is to be noted that India is not party to the 1951 Refugee Convention, which sets out the responsibilities of nations that grant asylum. This allows the Government of India to pick and choose the type of refugees it will accept and reject, limiting their answerability in privileging certain groups over others. The hostility and apathy are not just limited to immigrants. In October 2018, thousands of migrants from the Hindi-speaking states of Uttar Pradesh, Bihar and Madhya Pradesh fled the western state of Gujarat in the wake of violence against them (10).

Globally, anti-immigrant policies and political contestations such as these place migrants and refugees at a disadvantage, amplifying their precarity in the social-economic and political worlds they inhabit. Owing to their migrant status they have limited capacity to negotiate secure employment and access to education, health, food, housing and sanitation (11). These vulnerabilities have been exposed and amplified in the current Covid-19 crisis, where the imposed lockdown, ban on movement within the country and suspension of public transport at short notice left millions of low-income migrants stranded and starving. A state's response to a crisis is largely shaped by policies and systems that are already in place (12). In this instance, the structural gaps in existing policies and systems for migrants were exposed, and the State's apathy and failure to address the needs of low-income internal migrants and avert the humanitarian tragedy that ensued were glaring. Reports emerged of these vulnerable groups being lathicharged and frog-marched on interstate highways for "flouting" lockdown measures, and sprayed with disinfectants $(13,14)$. Against the backdrop of the pandemic, the Indian mainstream media played a pivotal role in steering public discourse on migrants by portraying them as "subjects of charity, objects of (mis)governance and bodies of disease and stigma" (15).

\section{Media and migration}

The role of the media in shaping public discourses is well established. Besides being a source of information, they play a critical role in setting agendas by deciding what issues merit coverage, and in framing these issues by representing events and people in particular ways $(16,17)$. Entman defines framing as a method to "select some aspects of a perceived reality and make them more salient" (18).

How does such framing occur? Two common routes of persuasion can be identified in the media. First, the central route, whereby information is elaborated using logical arguments, deliberate wording and highlighting certain information to influence an individual's views and opinions (19). Second, the peripheral route of persuasion, where cues (for example, repeatedly showing visuals of people of a particular ethnicity for crime reportage) take precedence over information (20).

Studies on print media coverage of migration indicate that while reportage of migration is diverse, involving a range of issues and perspectives, there is less variation in the way the migration process and migrants are framed $(21,22)$. Across different time periods, media and migration studies have found that the press often vilifies migrant communities, portraying them as a threat to society, while narratives on their rights are less frequent (23). A second frame is that of victimhood, where the media feed into the institutional expectation that helplessness is a migrant/refugee characteristic. In this instance, migration is presented as a "problem" to be solved and/or migrants portrayed as nameless "passive victims" (24) crossing borders in need of help. In contrast, highlighting migrants' contribution to the society and economy, where they are framed in a positive light and as heroes, has waned in the media even as their economic contribution has been acknowledged in scholarly literature (25). Scholars emphasise a number of ways through which the media constructs these frames: for example, by excluding migrants' voices, removing context from reporting, exaggerating facts, and overestimating their numbers $(21,23,26-29)$.

The glaring neglect and omission of migrants, immigrants and refugees as a vulnerable population needing support in the wake of the pandemic, coupled with debates on citizenship preceding the outbreak, necessitate research on the role of the Indian media in crystallising these debates; how they cover migrants and their health and welfare. While there is extensive literature from other parts of the world linking the media and migration, such attention is lacking in India. Globally, and in India, we found no study that undertakes an in-depth analysis of media portrayal of migrants and migrants' health.

Addressing this gap, our study aimed to examine the Indian print media's portrayal of migrants and refugees in general and in relation to health, between January 1, 2017, and December 31, 2018, the period following the introduction of the Citizenship Amendment Bill in Parliament. Two specific questions guiding the research enquiry were: How are migrants (and their health) framed in the English language print media? How does the application of frames vary based on the social position of migrants?

\section{Methodology}

A systematic review and frame analysis of migration-related articles in three newspapers were conducted, alongside an examination of how migrants' social position based on their religious identity, ethnicity, nationality, gender, and socioeconomic status influenced the print media's representation of them.

For the review and frame analysis, we sourced articles from the LexisNexis database, which provides a searchable database of newspaper articles. We searched for all major mentions of the terms "migrant" OR "immigrant" OR "refugee" OR "migration" in each of the sample newspapers for the period between January 1, 2017 and December 31, 2018. Letters to the editor and articles with high similarity were excluded. The search brought up 4,763 news reports, features and editorials which include the search terms in the headline, body or index. Of these, frame and content analyses were done for 1,111 news reports and editorials that directly referenced migration, migrants, immigrants, immigration and refugees - terms that were routinely used interchangeably - in India.

Three newspapers - The Times of India, The Pioneer and The Telegraph - were chosen for analysis based on their readership, geographical reach and their perceived political leaning, ie The 
Times as centrist, The Pioneer as right-leaning and The Telegraph as leaning to the left. All three are general interest newspapers in broadsheet format. While The Times of India has a readership of 15.2 million across the country (30), The Telegraph and The Pioneer, whose circulation is largely limited to the eastern and the northern states of India, have a combined readership of 1.7 million. The Times of India has multiple editions and our search covered all of them. Our decision to limit analysis to these three newspapers was determined by the availability of papers in LexisNexis. While we acknowledge that the reach of the English language press is limited compared to India's regional-language newspapers, it is still widely regarded as holding a critical position in the political, social and cultural spheres of India's urban centres (31). The overall newspaper readership in India grew from 407 million readers in 2017 to 425 million at the end of the first quarter of 2019 (32). Additionally, newspaper articles are also published online, extending their impact beyond local readership, and anchoring debates and associated stories in the broadcast media.

We combined frame and content analyses of identified articles. Frame analysis is embedded in a social constructivist paradigm - a sociological theory of knowledge according to which human development is socially situated and knowledge is constructed through interaction with others. Located in the tradition of Critical Discourse Analysis, such an approach enabled a reflexive process that impacted the results and their interpretation (33).

Frame analysis has been utilised by media and migration scholars worldwide, not just to study how migrants are portrayed in general, but also to explore the impact of such representation on the audience ie how this framing shapes public discourse $(21,22,25)$. However, no study to date has examined how mainstream media reports and frames health issues of migrants. Further, literature examining media representation of migrants does not sufficiently account for differences in migrants' social position other than migrant status and the administrative category/ group they belong to (refugees, asylum-seekers, undocumented migrants). Addressing this gap is critical as migrants in India are a particularly heterogeneous group, representing diverse castes, ethnic/ indigenous group, class and other social positions and identities. Content analysis has been used by scholars to study stereotypes reinforced by the media through the use of certain keywords, stock phrases and images, and sources of information and sentences that provide "thematically reinforcing clusters of facts or judgments" (21). For the current study, process documentation and personal observations in the process of selecting and analysing articles created space for reflection and guided the research process.

Drawing on Entman's work (18), this study defined frames as being composed of the following four aspects: (i) a definition of an issue or problem; (ii) assignment of a cause or responsibility to it; (iii) passing a moral judgement on its implications, and (iv) reaching a possible solution. The data analysis was done in two parts - a) frame and content analyses of general articles related to migrants and refugees in India and b) frame and content analyses of articles on migrants' and refugees' health (exclusive focus on health of migrants and refugees and the wider determinants), and migration and population health (focus on perceived impact of migrants' mobility on the health of the general population).
The 1,111 news reports, features and editorials were manually examined by the first author for the dateline (date and place of writing), the subject migrant/refugee group, the issue-focus, the frames adopted, the voices quoted, the frequency/ occurrence of certain words used to describe migrants, and the length of each article. The emergent themes were mapped in consultation with the second author but not quantitatively analysed, except if they were related to health. Paper-specific differences in reporting were also noted.

In addressing the second question, we adopted an intersectionality approach. A term coined by American sociologist Kimberlé Crenshaw (34), intersectionality is a theoretical framework for understanding how various aspects of a person's social position and identity interact to create different modes of discrimination and privilege. This approach is particularly useful in understanding migration and the risks and benefits it poses to migrants' mental and physical wellbeing, which is influenced by diverse factors such as nationality, gender, ethnicity and class, among others, as well as migration processes and laws and policies that govern these (35). In the current study, while reviewing articles, we noted the different categories of migrants focused on (eg refugees, internal migrants, cross-border migrants) as well as any reference to other aspects of their social position (eg their nationality, state of origin, ethnicity, religious identity, gender, migrant status and socio-economic status) in relation to the frames.

\section{Results}

\section{Framing migrants and refugees - overall coverage}

Three key ways of framing migrants were discerned from a review of sample articles - victim, villain, hero - covering a range of issues (eg crime, health, policy). These frames served as a useful guide for positioning and comparing a broad range of perspectives. Table 1 presents these frames along with the frequency of occurrence and the issues to which these frames were applied.

Migrants and refugees were most frequently framed as a threat to the local population $(47.07 \%, n=523 / 1,111)$, followed by the victim frame $(46.35 \%, n=515 / 1,111)$, which portrayed them as victims of violence and discrimination or as beneficiaries of state (humanitarian) assistance. The least popular $(6.57 \%, n=73 / 1,111)$ was the hero frame that recognised migrants' contribution to the economy and to infusing cultural dynamism in society.

The frequency of different frames varied in the sample newspapers. The proportion of articles framing migrants and refugees as villains and a threat was highest in The Telegraph (59.32\%, $\mathrm{n}=175 / 295)$, while The Times of India $(49.36 \%, \mathrm{n}=$ $317 / 642$ ) and The Pioneer (50.56\%, $n=88 / 174)$ used the victim frame more frequently than the threat frame. Figure 1 shows this variation across the three newspapers.

The difference in framing is distinct between the sample newspapers. For example, when a legislator called for Rohingya refugees to be shot and "eliminated" if they didn't leave India, the differences in coverage by The Pioneer and The Times of India were apparent, as evident in the opening paragraphs of the stories:

"Bangladeshi infiltrators and Rohingya refugees should be shot dead if they refuse to leave the country honourably," said a BJP MLA here (36) (The Pioneer, July 31, 
Table 1: Frames and broader themes in articles related to migrants and refugees

\begin{tabular}{|c|c|c|}
\hline Frame & Issues covered & Frequency \\
\hline Victim & $\begin{array}{l}\text { Housing, social discrimination, working conditions, crime (victims of trafficking, } \\
\text { mob violence, forgery, physical and sexual abuse), lack of access to healthcare, } \\
\text { disenfranchisement, violation of human rights, discrimination based on race, } \\
\text { ethnicity and religion, beneficiaries of financial aid/incentives, poverty alleviation } \\
\text { programmes, ex-gratia, potential target for rehabilitation programmes (education, } \\
\text { health, livelihood), victims of disease/outbreak along with other members of the } \\
\text { public }\end{array}$ & $512 / 1,111(46.08 \%)$ \\
\hline Villain/Threat & $\begin{array}{l}\text { Terror threat, demographic change, burden on the government and competition } \\
\text { for scant resources, crime (engaged in arms trade, drugs smuggling and peddling, } \\
\text { forgery of identification papers, rape, murder, land encroachment, cyber fraud), } \\
\text { surveillance and border control, carriers of infectious diseases, reason for poor } \\
\text { sanitation in cities }\end{array}$ & $526 / 1,111(47.34 \%)$ \\
\hline Hero & $\begin{array}{l}\text { Human agency, contribution to host and home economy, poverty alleviation, } \\
\text { remittance }\end{array}$ & 73/1,111 (6.57\%) \\
\hline
\end{tabular}

2018). The story had no quote countering him.

"Rohingya Muslims and Bangladeshis living illegally in India should be shot dead if they do not leave the country," said BJP MLA from Goshamahal Assembly constituency Raja Singh. He is known for his hardcore Hindutva remarks (37) (The Times of India, July 31, 2018).

The article went on to present voices from human rights organisations and other political outfits criticising the leader for his inflammatory remarks. While the former article framed migrants as a "threat" with the legislator being the only source of information, the latter takes a more humanitarian view of the subject, portraying refugees as victims of a hostile system.

\section{Representational frames}

This section presents how the three frames were utilised in coverage of migrants

\section{Migrants as threat}

Articles that framed migrants as villain portrayed them as being dangerous, violent, criminals, and as a threat to public order and safety of native people. They are also shown as competitors for scarce jobs and state funds, and the reason for increasing unemployment and insecurity in the destination states. Within this frame, two recurrent narratives were identified:

\section{- International migrants as threat to national security}

Vilification of migrants was distinct in The Pioneer which, although it had fewer articles, frequently used inflammatory language, especially while alluding to Muslim migrants from Bangladesh and Rohingyas from Myanmar.

According to sources, these (Bangladeshi) immigrants are notorious in nature. We need to take steps to ensure our people are safe. (38) (The Pioneer, November 28,

\section{8).}

According to reports, about 11 lakh Rohingyas have already reached Bangladesh and may try to infiltrate into India. The Government of India has taken the righteous decision to not bow down to international pressure. (39) (The Pioneer, May 1, 2018)

In both editorials from which the above quotes are excerpted, vague statistics, attributed to even vaguer sources, are used to paint a picture of a crisis, while words like "infiltrate" and "notorious" evoke fear. All three papers frequently used waterrelated metaphors like "inflow","spurt" and "flushing out" while referring to migrants to create a sense of urgency and notion of scale, especially in the context of immigration from Bangladesh.

\section{- Internal migrants as criminals}

Frequent mention of migrants in crime reportage was observed in all the newspapers, along with a general tendency to attribute such crime to migrants, even when evidence was lacking. In some instances, migrants were vilified even after their innocence was proved. This was evident in the reporting of a case of child rape in Uttarakhand, where a migrant labourer was suspected by locals of perpetrating the crime. Covering police investigation that found otherwise, The Pioneer concluded:

Though a local may be the accused in this crime, there are various other crimes including murder which have been committed by those who are not natives of the state. (40) (The Pioneer, August 25, 2018)

Similar framing of migrants as potential criminals was found in other newspapers that frequently quoted unnamed sources (eg police officers):

Thefts and dacoity in Panambur, Mulki and Surathkal have been on the rise in the recent past. Police say these 


\section{Variation in frames used by sample newspapers}

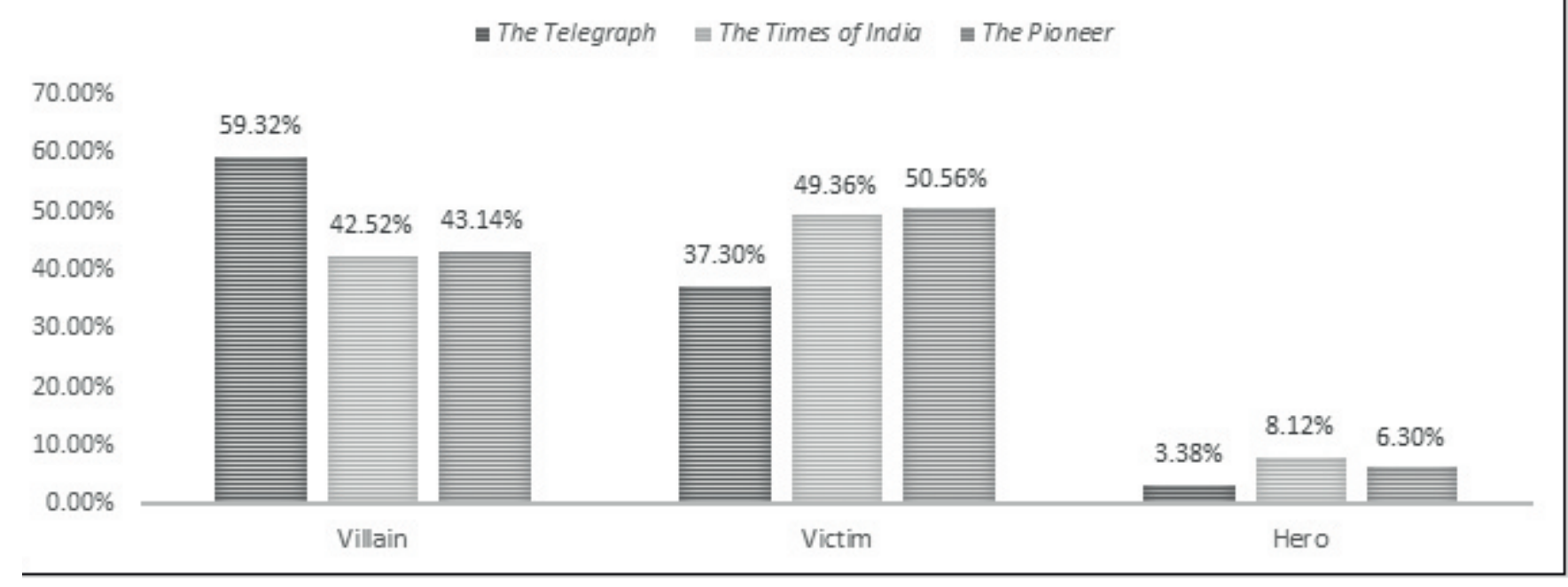

areas see a lot of migrant labourers and suspect their hand in the crime. (41) (The Times of India, October 28, 2017)

Associations with crime were also made indirectly through descriptions of neighbourhoods that have high migrant, refugee population as being overcrowded, with poor sanitation and high crime rates.

A large migrant 'Poorvanchali' population lives in these rickety buildings and makeshift structures in congested alleyways. The area is infested with criminals and gang wars are frequent. (42) (The Telegraph, July 2, 2018)

Numerous industries and a large migrant population offer the right environment for anti-social elements in Coimbatore and neighbouring Tirupur to camouflage themselves. (43) (The Times of India, July 8, 2017)

\section{Migrants as victims}

Although less common, the victim-framing portrayed migrants as victims of inequality and/or discrimination. Within this frame, a little more than half the articles were on low-income internal migrants. These presented migrants as a homogenous group, or clubbed them together with other marginalised communities, frequently referred to as "rural landless poor", or the "urban poor", or "poor settlers".

Cities in urban India are flooded with the poor. Over the years, due to high migration, poverty in the country is transiting from rural to urban largely. These groups, who live in clusters in big metros, are often victims of harassment and crime. (44) (The Times of India, December 8, 2017)

All the articles that framed select refugees and cross-border migrants as victims were accounts of their struggle for citizenship, documentation and their constant fear of deportation.

'Where will we go? We can't go to Myanmar. We'll all be dead,' said Ashadullah, a Rohingya, who moved to the shelter (in Chennai) from a camp in Jammu and Kashmir. (45) (The Times of India, December 13, 2018)

\section{Migrants as heroes}

Migrants and refugees represented as contributing to society, and having agency - to live, work, succeed and question - featured the least among other frames in all three papers. A quarter of the articles that used this frame were reports and editorials from Gujarat following violence against migrant workers in October 2018. When locals attacked migrant workers from the Hindi-speaking belt over allegations that a migrant worker was involved in raping a child, local businesses and the media rallied behind the workers. They maintained the state would be crippled economically if the workers left and appealed for peace.

Migrant workers are indispensable to the Indian economy. The mobility of labour pushes the wheels of the economy forward. (46) (The Telegraph, October 9, 2018)

A majority of the reports presented migrants as passive. This is evident from fewer voices being recorded from these communities: $74.5 \%(n=757 / 1,854)$ of the quotes in these sample articles were attributed to the police, government officials and unnamed sources. $99.04 \%$ of the articles that quoted migrants and refugees $(n=310 / 313)$ were those that framed them as victims (eg: victims of crime and discrimination, lack of access to essential services) and heroes (eg: contribution by migrant entrepreneurs and workers to the host economy). Only three articles that framed migrants as a threat included voices of migrants. Figure 2 shows the sources of information in articles on migrants and refugees.

\section{Unpacking heterogeneity in "migrant" representations using an intersectional lens}

On examining the categories of migrants and the different aspects of their social positions (class, ethnicity, religion etc) that newspapers reported on, we found across the three newspapers, the highest media coverage was for internal (inter-state and intra-state) migrants and internally displaced persons $(46.80 \%, n=520 / 1,111)$, mostly low-income migrants from the Hindi-speaking belt, West Bengal and Assam; followed by Bangladeshi immigrants $(20.16 \%, n=224 / 1,111)$ 


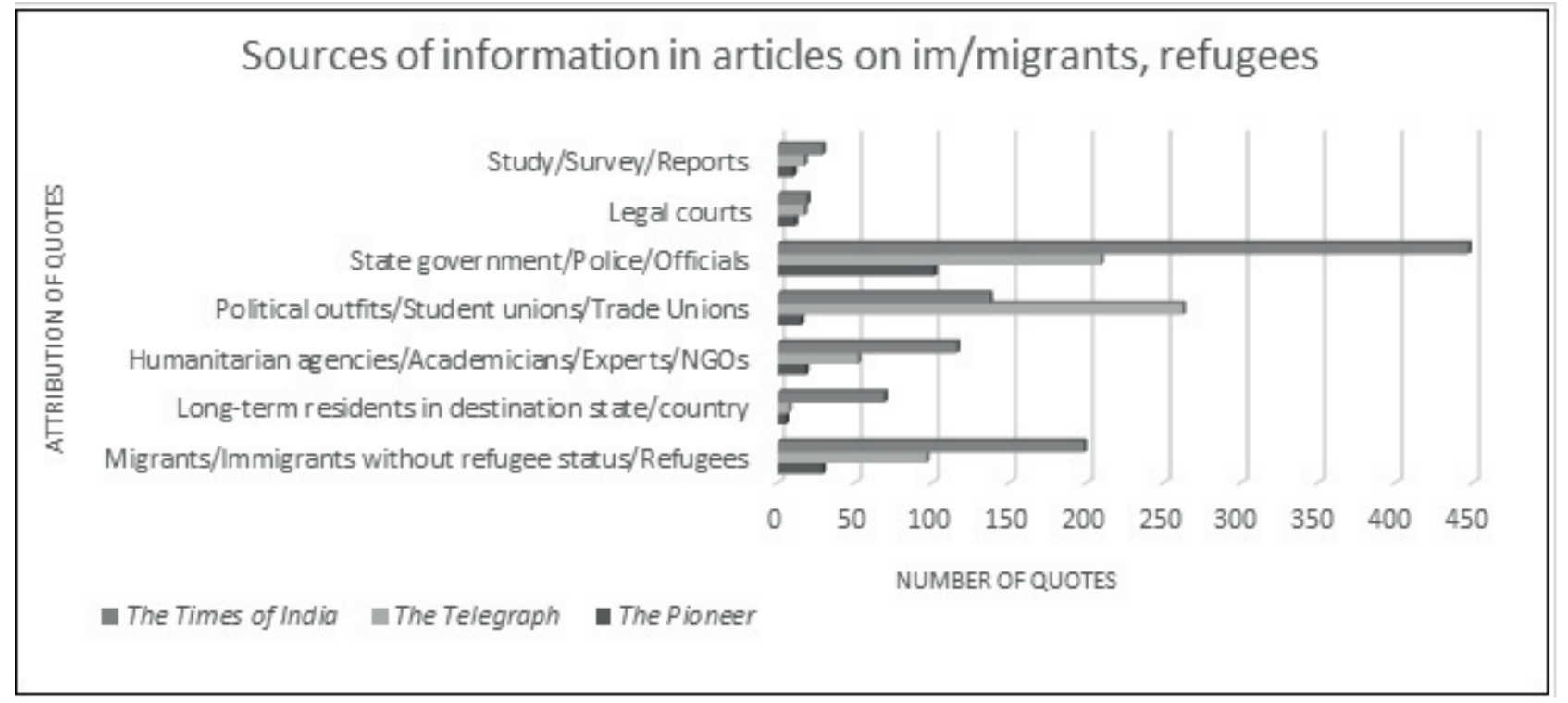

and Rohingyas $(14.67 \%, \mathrm{n}=163 / 1,111)$.

Significant variation was found in application of frames to migrant groups based on their social position. From the data collected, religious identity and ethnicity and nationality appeared as the most prominent markers determining whether they were viewed as heroes, victims or threats.

Figure 3 provides a breakdown of the three frames based on type of migration, migrant ethnicity/nationality.

The Muslim majority Rohingyas and Bangladeshi immigrants were portrayed more frequently as a threat compared to other migrants and refugees (for example, Sri Lankan and Tibetan refugees), by all three newspapers. Most of the articles on cross-border migrants (from Pakistan, Bangladesh and Myanmar) made a clear distinction between those who identify themselves as Hindus and Muslims. The former, if they were identified by their religion, were framed only as victims of hostility in source states and heroes for the extent of assimilation in the destination states. No article vilified them. This extends to the media's portrayal of internal migrants too. For example, Kashmiri Pandits, an upper-caste Hindu Brahmin community who fled the insurgency in Muslim-dominated Kashmir Valley in the 1990s, were represented only as victims of the "Muslim insurgency" (47) and heroes for their contribution to the economy in their destination states/cities (mostly in the national capital region).

This excerpt of an editorial in The Pioneer (25 September 2017) shows how the intersection of religion and migration influences framing:

The festering Rohingya crisis has caught international attention with Rohingyas having earned the epithet of being 'one of the most persecuted minorities in the world' by the UN, even as the body never bothered to show scant sympathy for the persecuted Hindus in Bangladesh (39).

The editorial argues that Bangladeshi Hindus should be granted refugee status or citizenship in India, while filtering out Muslims, as "more than $90 \%$ of the crimes in border states are committed by Muslim migrants from Bangladesh". No source for this statistic was provided.
It is to be noted that reference to "illegal Bangladeshi immigrant" can take different meanings based on the source. When representatives of the ruling right-wing party refer to Bangladeshi immigrants, their primary targets are Muslims, but to political outfits and unions in Assam (which is divided more on ethnic lines), Bangladeshi immigrants could be Hindus and Muslims from either Bangladesh or Bengalis from the neighbouring state of West Bengal (48). A majority of the articles on internal migrants (framed them as victims ( $n=296 / 520)$ of crime, with poor working and living conditions, and lacking access to basic facilities); $33.26 \%$ $(n=173 / 520)$ portrayed them as a threat, and 9.8\% $(n=51 / 520)$ of the articles framed them as heroes highlighting their entrepreneurship and contribution to the economy. 9\% $(n=100 / 1,111)$ of the articles did not provide details of the type of migrants being referred to. More than half $(n=52 / 100)$ of these articles used the term "migrants" and "immigrants" more to raise alarm than to inform, while $42.2 \%(n=38 / 90)$ portrayed them as victims.

We also noted the absence of reportage of certain migrants: skilled internal migrants and migrants from north-east India (who are vulnerable to discrimination in other parts of India because of their ethnicity) and migrants from Nepal.

\section{Migration and health}

Of the 1,111 articles on migrants and refugees in India in the sample newspapers, $8.01 \% \quad(n=89 / 1,111)$ linked migration with health. Out of these, only $20.2 \%(n=18 / 89)$ focused primarily on migrants and migration. In all the other articles, migrants were clubbed with other marginalised communities like the urban poor, and groups categorised as high-risk for communicable diseases like HIV/AIDS and TB (truck drivers, men who have sex with men, female sex workers, etc).

Notably, $42.69 \%(n=38 / 89)$ of the health focused articles reported on the health status or issues affecting migrants (and other marginalised groups) and the wider determinants of their poor health; whereas the majority $(57.3 \%, n=51 / 89)$ reported on the impact of migration on the health of the local population.

We describe below specific issues and topics covered under 


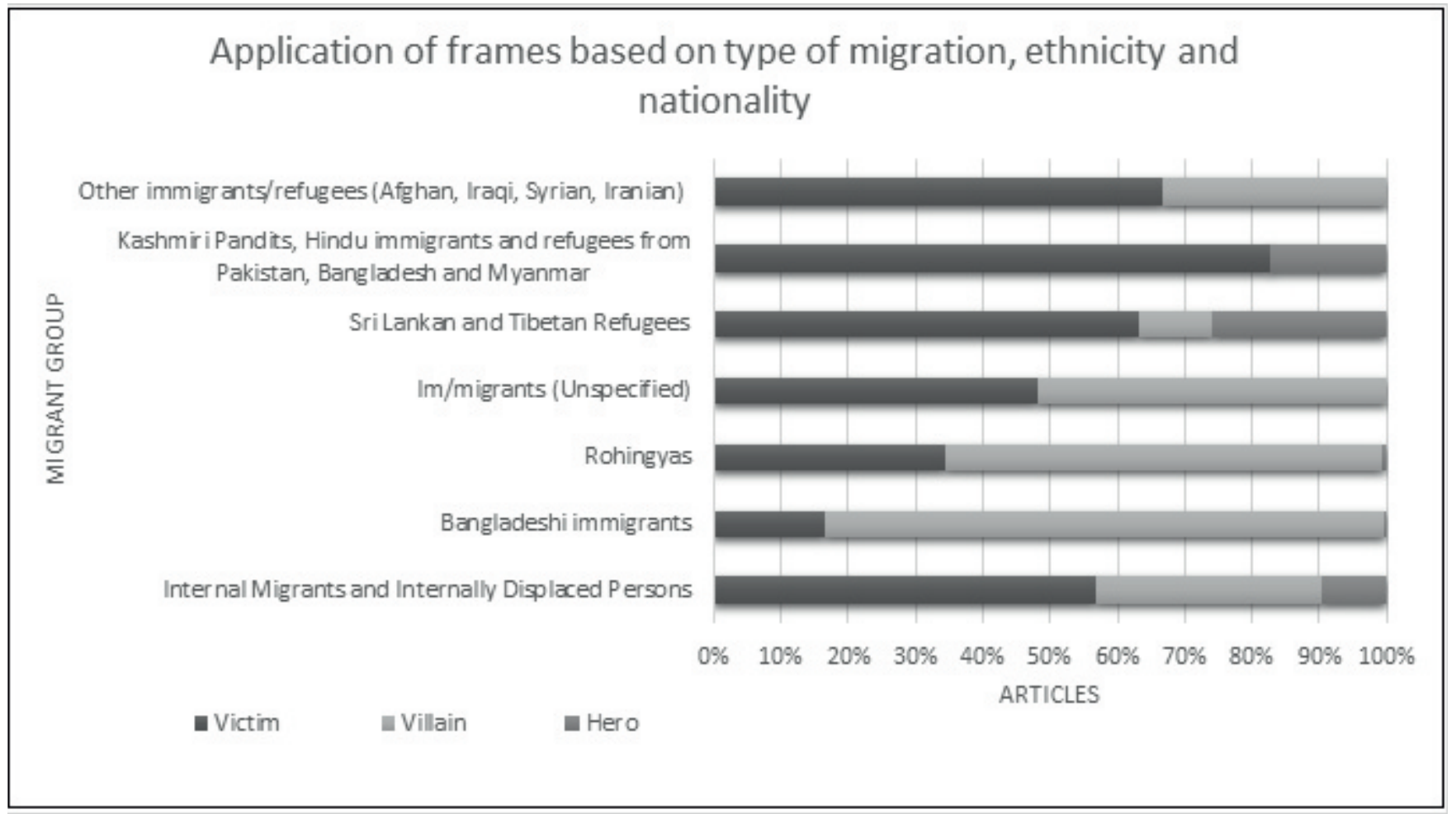

each of the two categories: migrants' health, and the impact of migration on population health. In all three newspapers, there was no distinction between different migrant groups in articles on health. They were collectively referred to as "migrants" or the "migrant population"; while no specific reference was made to the health of refugees.

\section{Migrants' health}

A majority of the 38 articles $(84.2 \%, n=32 / 38)$ in this category portrayed migrants as in need of state assistance (victim/ humanitarian frame), though often blamed them for their status. These articles were short, less than 200 words, and mostly announcements of state programmes.

Preventive healthcare was the most widely covered theme under migrants' health (Figure 4), but mostly included vaccination drives for children, and awareness programmes for HIV/AIDS and TB among migrants. There was no reporting on the lack of basic amenities such as housing and drinking water, or the factors underlying migrants' limited uptake of aanganwadi and other facilities.

Access to healthcare, the second most widely reported issue under migrants' health, focused on healthcare provision through government-led camps; only two of these reported on the barriers faced by migrants in accessing healthcare.

Six of the eight articles on sanitation blamed migrants for their squalid living and work conditions and cited this as reason for their poor health outcomes, especially in relation to infectious diseases. Two articles presented migrants in the victim and humanitarian frame, highlighting their vulnerability to diseases - exacerbated by their migrant status - and delved into the lack of sanitary facilities and provision of healthcare for them by the state. This difference in framing is discernable in this reportage of open-defecation by two of the sample newspapers:

The headline of an article in The Telegraph on civic officials in Jamshedpur penalising those defecating in the open read: "Poop cuffs fails to raise stink" (49).

The report went on to say: Thousands of urban slum residents, migrant labourers and the homeless - many being women and children sully these spaces.

A subsequent TOI report (50) framed the issue differently: "Toilets few, threat of fines fails to stop open defecation," read the headline, pointing to the lack of facilities for these communities. The article by The Telegraph, on the other hand, had placed the blame squarely on migrants with no mention of the state's role in providing facilities.

\section{Migration and population health}

Articles that reported on population health implications of migration tended to be longer, between 300-570 words, and mostly $(92.15 \% ; n=47 / 51)$ represented migrants as a threat to population health.

Articles focused on infectious diseases $(86.27 \%, n=44 / 51)$ and sanitation (13.72\%, $n=7 / 51)$. Increased prevalence of communicable diseases like HIV and TB in destination states was attributed to a rise in migration in $38.29 \%(n=18 / 47)$ of these articles. In $46.8 \%(n=22 / 47)$ of the articles, migrants are framed as a threat by being either carriers or potential carriers of diseases; being blamed for poor sanitation in cities and the source of outbreaks $(14.89 \% n=7 / 47)$. Only four articles identified migrants as being victims of a disease/outbreak along with other members of the local community.

\section{Discussion}

Frame analysis of articles on migration in the sample 
Figure 4: Topics covered under migrants' health

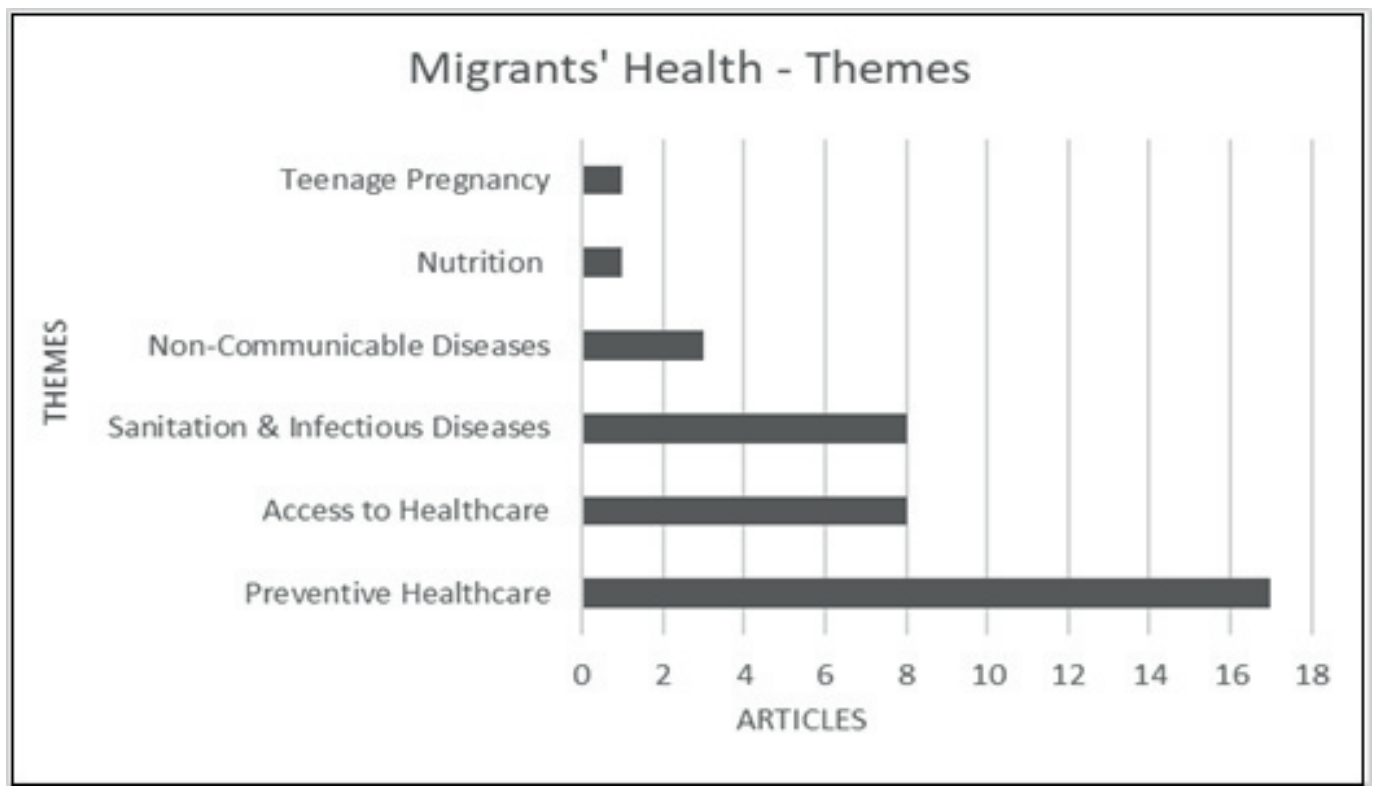

newspapers revealed three main frames, applied to a range of issues (crime, health, economy, poverty alleviation, security and border control, urban development, among others) and involving different migrant and refugee groups. Overall, migrants and refugees were most frequently framed as a threat, while the second most recurrent frame presented them as victims. The hero frame was used the least. Applying these frames to health, the study found that the threat/villain frame was most frequently applied, pathologising migrants and projecting them as carriers of infections and diseases; a view that appears to have intensified in the Covid-19 crisis (12).

We discuss our findings under three main issues with regard to media representations and their implications for policy prioritisation of migrants' health and well-being.

First, the media homogenises migrants' experiences and erases their unique contexts of structural vulnerabilities and agencies. While the sample articles make a distinction between different migrant groups in their reportage of crime and national security, while covering health, we observed that not only do the media fail to make this distinction, but they also ignore the distinct problems migrants face compared to other marginalised groups. Migrants' lived realities and needs are invisibilised in the media narratives by failure to report on their health, livelihoods and other needs and lived realities, as well as relying primarily on the views and accounts of others (eg State representatives). Only 18 (20\%) of the 89 health-focused articles were primarily about migrants, while the rest clubbed them with other marginalised groups. McKay et al (51) argue that migrants' health issues and their context are distinct from those of other marginalised communities and the effect of migration itself on their health is complex and varies across migrant groups. Studies have shown that migrant workers in India face multiple challenges like occupational hazards because of unsafe work conditions (52), higher prevalence of chronic diseases compared to those with no history of migration (53) and insufficient nutritional intake (54), subjects that continue to be ignored by the media. The media's narrow focus on infectious diseases outbreaks, preventive care and sanitation issues while covering migration and health could also be because almost all the stories linked to health were filed from the destination states/cities, and newspapers tend to give salience to those aspects of stories that were deemed of interest to their readers (55). We also noted the omission of gender and an absence of women migrants in migration narratives. Despite women forming a major part of the migrant workforce in India (5) and studies showing significant gaps in migrant women's access to healthcare (56), no article specifically addresses the health and experiences of women migrants.

Second, despite the homogenous representation of migrants in the newspapers, our study, by utilising an intersectional lens, found variation in frames based on the social position and identity of migrants. Most prominent axes along which their positionality was defined were: religion, nationality, ethnicity and socio-economic status. While all the migrants in the sample newspapers were mostly projected as a threat $(47.07 \%)$ or as victims $(46.35 \%)$, there are indications that the frames (and the language used) varied based on how close their identities and positionalities were to those of the majority (dominant) community in the region served by the paper. The closer, the less likely they were to be framed as a threat. For example, all the articles on Kashmiri Pandits, most of which originated from NCR and Jammu or featured in editions here, framed them only as heroes for their contribution to the economy and to the arts and as victims of militancy and displacement $(47,57,58)$. Most reports on internal migrants coming from Odisha, Bihar, Jharkhand, West Bengal and Assam were from southern states (Tamil Nadu and Kerala) and framed them as victims of discrimination or as a threat (crime), with their contribution to the economy constituting less than $10 \%$ of the coverage on them. Studies, on the other hand, have shown that this silent workforce contributes more than 2\% of the country's Gross Domestic Product and is critical for building cities, maintaining household economies, and keeping consumption growth in the places of their origin through remittances $(12,59)$. Bangladeshi immigrants, on the other hand, are almost universally framed as a security threat and described as "illegal migrants", "infiltrators", "Muslim terrorists" and "Bangladeshi terrorists". The term "illegal" is often criticised by 
scholars, not only because it "stresses criminality", but it is also misleading and demeaning (60). It also does not address the multiple "in-between" situations (61) as evident in the changing policy climate in India and the ambiguous definition of citizenship. Studies have shown that "illegality" leads to social and biopolitical exclusion, which often translates into adverse living and working conditions, poverty, the perpetual fear of arrest and deportation, chronic stress, and other factors that interact to heighten vulnerability to illness and injury (6264). This raises the concept of what French anthropologist and sociologist Didier Fassin calls "biolegitimacy", questions of morality and judgement that lead to the unequal evaluation of human suffering and human lives (63). In this study, the limited corpus on health, for example, mostly pertained to internal migrants. Refugees and undocumented immigrants are completely absent in this discourse, but are prominent in themes related to crime and security. There is clearly an unequal evaluation of human health and suffering here by the media.

Third, through frames - and the use of certain terminologies and references in constructing these frames - the media plays a crucial role in maintaining, if not widening, social gaps and inequalities. It enables "othering", the dual process of creation of an imagined included "us" through the construction of an excluded "other" (65), by the dominant/majority group, deepening social divisions and hierarchy in the process. These divisions are, however, not naturally occurring, but socially constructed (66). The differentiation is created by assigning opposing value-laded binaries (virtuous/corrupt, normal/ abnormal) to both groups. Words like "our" and "us" furthers the "othering". The process is also used as a means to maintain inequality so power can be exerted. As Cottle argues (67), through these value-laden binaries the media audience are invited to construct a sense of "who 'we' are in relation to who 'we' are not". In our study, this process is discernible more prominently in negative frames, where quotes and descriptions are used to reinforce stereotypes and delineate group boundaries. Most of the articles, through attribution or through comments and editorials, consistently put an emphasis on a collective "us" needing protection from "them". The fear of the other is used to solidify the biases and prejudices that exist along class, caste, religious and ethnic divides. The division can be explicit or implicit. An example of the latter is description of neighbourhoods where poor migrants stay as opposed to where local residents stay, and frequent references to their hygiene and sanitation practices. Studies have shown that such "othering" could cause anxiety and poor mental and physical health among these communities (68), and an erosion of trust in public services (including health) resulting in lower uptake of preventive interventions such as immunisation, and avoidance of healthcare (69).

We observed that stereotypes and prejudices concerning migrants are reinforced through the use of frames as narratives, which are often built on the perceptions of the majority or dominant class (government officials, right-wing organisations, outfits, etc) and are devoid of migrant voices and those of minorities For example, none of the articles on Bangladeshi immigrants where they are framed as a threat had a voice from the community countering this negative perception. The absence of migrant voices as sources in the media can deprive the audience of a complex understanding of migration issues. It can also have negative consequences for migrants' integration and their sense of belonging (25). By robbing them of their voice, the state and media shape our image of who a migrant is.

We also observed a lack of nuance in articles that frame migrants as victims, the second most recurrent frame in our corpus. While victimhood can be beneficial in invoking empathy and sensitivity to the precarious contexts and lives of migrants, with moving personal stories driving campaigns to end indefinite detention of migrants and asylum seekers (21), it is also limiting. The biggest drawback is it relies primarily on emotional reactions which do not necessarily contribute to a nuanced, well-informed public and political debate on migration. Nor does it contribute to good policy making (21). It also shows migrants as lacking agency, ie, the ability to act in order to advance their own and their families' interests. The decision to migrate and the journey followed is a complex process that involves decisions and exercise of agency for migrants to leave a familiar setting in the hope of a better life. The question of migrant agency is crucial to how academics, policymakers, and activists frame and understand migration. In our study, agency is one of the variables included in the hero frame - the least utilised frame $(6.6 \%$ of all articles). Extent of assimilation and contribution to the host society emerged as the cornerstones of the hero frame. For example, three articles within this frame were from Kerala where migrant workers from Hindi-speaking states were rewarded for learning Malayalam, the local language. This corroborates Spoonley and Butcher's observation that migrants' contributions and lives are presented as success only if framed within the dominant culture (70). To this end, the narrative of assimilation works to "domesticate" a certain type of migrant within the majority community and serves as a mechanism through which "they" become "us". In this process, the "difference-oriented" rhetoric gets solidified, and exclusion and segregation along other ethnic, caste and religious lines legitimised by culturally homogeneous majorities.

\section{Conclusion}

The current hegemonic discourse in the mainstream Indian print media on migrants and refugees is selective, premised on perceptions of the dominant class (government officials, right-wing organisations, outfits, etc) and advances a poor understanding of migration and migrants' health. Articles rely heavily on majoritarian views, stereotypes and information handed to them by state authorities. The health of migrants is given the least priority among other themes, and even within the limited corpus there is a tendency to pathologise migrants and treat them as dangerous for the health of local populations, while sparse attention is given to their entitlements, more specifically, their poor health status and rights. These portrayals fail to capture the dynamism and circular movement that characterises migration in India, and risk vilifying or victimising migrants and impeding any potential for their assimilation in the societies to which they contribute. While there has been an evident shift in the Indian media's reportage of migrants in the ongoing Covid19 crisis - an increased focus on individual stories, more migrant voices being documented, questions raised over government policies, and recognition of migrants' contribution in various sectors - it is imperative to note that the pandemic has only exacerbated existing vulnerabilities. As the Indian economy reopens, migrants are now gradually returning to living precariously in cities.

Most studies that highlight the importance of the media in 
setting agendas and shaping public discourses draw from van Dijk's theory on the two-way relation between power and discourse in the media (23). On the one hand, power controls these discourses, and on the other, these discourses themselves have the ability to influence power and decision making. Our study found that in the two years leading up to the pandemic, the print media's coverage on migrants was through a narrow range of issues (crime, national security, disease outbreaks that they are deemed responsible for), that largely relied on stereotypes and information handed out by the State. Bestowed with the power to set the agenda for issues of political and social significance (71), the media, through acts of commission and omission, has contributed to amplifying the health and socio-economic crisis faced by migrants.

\section{Conflict of interest and funding support}

None declared

\section{References}

1. Ministry of Finance, Govt of India. Economic Survey of India (20162017). New Delhi: Government of India; 2017[cited 2020 Jun 6] Available from: https://www.indiabudget.gov.in/budget2017-2018/ es2016-17/echapter_vol2.pdf

2. Deshingkar P, Akter S. Migration and human development in India. New Delhi: United Nations Development Programme (UNDP); 2009 [cited 2020 Jun 6]. Available from: http://hdr.undp.org/sites/default/files/ hdrp_2009_13.pdf

3. Akinola .B, Krishna AK, Chetlapalli SK. Health equity for internal migrant labourers in India: an ethical perspective. Indian J Med Ethics. 2014 Oct-Dec; 11(4):232-7. Doi: 10.20529/IJME.2014.058.

4. United Nations Development Programme. Human Development Report 2009. Overcoming barriers: Human mobility and development. New York: UNDP; 2009 [cited 2020 Jun 6]. Available from: http:// hdr.undp.org/sites/default/files/reports/269/

hdr_2009_en_complete.pdf

5. Registrar General \& Census Commissioner, India. Census India 2011 New Delhi: RG \& CC; 2011 [cited 2020 Jun 6]. Available from: http:// www.censusindia.gov.in/2011Census/pes/Pesreport.pdf

6. Karmakar R. Over 19 lakh excluded from Assam's final NRC Thehindu.com. 2019 Aug 31 [cited 2020 Jun 5]; Available from: https:// www.thehindu.com/news/national/over-19-lakh-excluded-fromassams-final-nrc/article29307099.ece

7. United Nations High Commissioner for Refugees. Rohingya emergency. UNHCR; 2019 Jul 31 [cited 2020 Jun 5]. Available from: https://www.unhcr.org/rohingya-emergency.html

8. Siegfried K. The Refugee Brief - 4 January 2019 [cited 2020 Aug 6]. Available from: https://www.unhcr.org/refugeebrief/the-refugeebrief-4-january-2019/

9. India: Rohingya have"terror"ties. Aljazeera.com. 2017 Sep 18 [cited 2020 Jun 5]. Available from: https://www.aljazeera.com/news/2017/09/ india-rohingya-muslims-terror-ties-170918134840406.html

10. Press Trust of India. Thousands of migrant workers flee Gujarat after alleged hate attacks. Economictimes.indiatimes.com. [Internet]. 2018 Oct 9[cited 2020 Jun 2]. Available from: https:// economictimes.indiatimes.com/news/politics-and-nation/thousandsof-migrant-workers-flee-gujarat-after-alleged-hate-attacks/ articleshow/66138037.cms?from $=$ mdr

11. Chatterjee CB. Identities in motion; Migration and health in India. Mumbai: Centre for Enquiry into Health and Allied Themes; 2006 Oct [cited 2020 Jun 6]. Available from: http://www.cehat.org/go/uploads/ Hhr/migrants.pdf

12. Samaddar R. Introduction. Borders of an Epidemic. In: Samaddar R, editor. Borders of an epidemic - COVID-19 and migrant workers. Kolkata: Mahanirban Calcutta Research Group; 2020 [cited 2020 Jun 6] pp. 123. Available from: http://www.mcrg.ac.in/RLS_Migration_2020/ COVID-19.pdf

13. PTI. Migrant workers returning home punished by cops for violating lockdown, made to hop like frogs. News 18.com. 2020 [cited 2020 Jun 3]. Available from: https://www.news18.com/news/india/migrantworkers-returning-home-punished-by-cops-for-violating-lockdownmade-to-hop-like-frogsmigrant-workers-returning-home-punishedby-cops-for-violating-lockdown-made-to-hop-like-frogs2552567.html
14. Gupta S, Mitra E, Sud V. Migrant workers sprayed with disinfectant in one Indian state. Cnn.com. 2020 Apr 1[cited 2020 Aug 6]. Available from: https://www.cnn.com/2020/03/30/india/india-migrant-workerssprayed-intl/index.html

15. Ahamed S. Epilogue: Counting and accounting for those on the long walk home. In: Samaddar R, editor. Borders of an epidemic - COVID-19 and Migrant Workers. Calcutta: Mahanirban Calcutta Research Group; 2020. p. 124. Available from: http://www.mcrg.ac.in/ RLS_Migration_2020/COVID-19.pdf

16. Bleich $\mathrm{E}$, Stonebraker $\mathrm{H}, \mathrm{Nisar} \mathrm{H}$, Abdelhamid R. Media portrayals of minorities: Muslims in British newspaper headlines, 2001-2012. J Ethn Migr Stud. 2015 Feb 9; 41:1-21.

17. Vliegenthart R, Boomgarden HG. Real-world indicators and the coverage of immigration and the integration of minorities in Dutch newspapers. Eur J Commun. 2007; 22(3):293-314.

18. Entman R. Framing:Toward clarification of a fractured paradigm. $J$ Commun. 1993 Dec; 43(4):52

19. Nelson TE, Kinder DR. Issue frames and group-centrism in American public opinion. J Polit. 1996; 58(4):1055-78.

20. Soderlund $M$. The role of news media in shaping and transforming public perception of Mexican immigration and laws involved. Law Psychol Rev. 2007 [cited 2020 Jun 4]; 31:167. Available from: https:// heinonline.org/HOL/LandingPage?handle=hein.journals/ Ipsyr31\&div=12\&id=\&page $=$

21. Crawley H, McMahon S, Jones K. Victims and villains: Migrant voices in the British media. Centre for Trust, Peace and Social Relations, Coventry University. 2016 [cited 2020 Jun 6). Available from: https:// pureportal.coventry.ac.uk/en/publications/victims-and-villainsmigrant-voices-in-the-british-media-2

22. Retis J, Benavides J. Glances toward Latin America: The discursive representation of Latin American immigrants in the Spanish and American press. Temas Portada. 2005; 8(2):93-114.

23. van Dijk T. News analysis: Case studies of international and national news in the press. New Jersey: Hillsdale; 1987.

24. Malkki L. Speechless emissaries: Refugees, humanitarianism, and dehistoricization. Cult Anthropol. 1996;11(3):377-404.

25. Gemi E, Ulasiuk I, Triandafyllidou A. Migrants and media newsmaking practices. Journalism Practice. 2012[cited 2020 Jun 5]; 7(3):266-81. Available from: https://www.researchgate.net/publication/ 263493687_Migrants_and_media_newsmaking_practices

26. Jacomella G. Media and Migrations: Press Narrative and Country Politics in Three European Countries. University of Oxford; 2010 [cited 2020 Jun 5]. (Reuters Institute Fellowship Paper). Available from: https://reutersinstitute.politics.ox.ac.uk/sites/default/files/research/ files/

Media\%2520and\%2520migrations\%2520Press\%2520narrative\%2520 and\%2520country\%2520politics\%2520in\%2520three\%2520Europea n\%2520countries.pdf

27. Georgiou M, Zaborowski R. Media coverage of the "refugee crisis": $A$ cross-European perspective. London: Council of Europe; 2017 [cited 2020 Jun 6]. Available from: https://rm.coe.int/1680706b00

28. Kressin N, Lin M. Race/ethnicity, and Americans' perceptions and experiences of over- and under-use of care: a cross-sectional study. BMC Health Serv Res. 2015 [cited 2020 Jun 6];15(1). Available from: https://www.ncbi.nlm.nih.gov/pmc/articles/PMC4590257/

29. Nadeau R, Niemi R, Levine J. Innumeracy about minority populations. Public Opinion Quarterly. 1993; 57(3):332-47.

30. Media Research Users Council. Indian readership survey Q1 2019. 2019 [cited 2020 Jun 3]. Available from: https://mruc.net/uploads/posts/ 8e428e54a95edcd6e8be593a7021a185.pdf

31. Chaudhry L. Can the digital revolution save Indian journalism? Columbia Journalism Review. 2016 Fall/Winter[cited 2020 Jun 3]. Available from: https://www.cjr.org/special report/ india_digital_revolution_startups_scoopwhoop_wire_times.php/

32. Malvania U. Print readership in India jumps $4.4 \%$ to 425 million in two years: Report. Business-standard.com. 2019 Apr 27 [cited 2020 Jun 3]; Available from: https://www.business-standard.com/article/currentaffairs/print-readership-in-india-jumps-44-to-425-million-in-twoyears-report-119042700079_1.html

33. Kuper A, Lingard L, Levinson W. Critically appraising qualitative research. BMJ. 2008[cited 2020 Jun 3]; 337:a1035. Available from: https://www.researchgate.net/publication/ 23156527_Critically_Appraising_Qualitative_Research

34. Crenshaw K. Mapping the margins: Intersectionality, identity politics, and violence against women of color. Stanford Law Rev. 1991 Jul;43(6): 1241-99.

35. Kapilashrami A, Hankivsky O. Intersectionality and why it matters to global health. Lancet. 2018 Jun 30;391(10140):2589-91. 
36. Shoot Bangladeshi, Rohingya If They Don't Leave: BJP MLA. Pioneer. 2018 Jul 31.

37. Mahesh K. Rohingyas staying illegally should be shot dead: BJP MLA. Timesofindia.indiatimes.com. 2018 Aug 1[cited 2020 Jun 5]. Available from: https://timesofindia.indiatimes.com/city/hyderabad/ rohingyas-staying-illegally-should-be-shot-dead-bjp-mla/ articleshow/65222099.cms

38. Dasgupta S. Illegal immigrants pose threat to India's integrity. Dailypioneer.com. 2018 Nov 25[cited 2020 Jun 7]. Available from: https://www.dailypioneer.com/2018/columnists/illegal-immigrantspose-threat-to-india---s-integrity.html

39. Verma JK. Rohingyas: A security threat. Dailypioneer.com. 2018 May 1 [cited 2020 Jun 8]. Available from: https://www.dailypioneer.com/ 2018/columnists/rohingyas-a-security-threat.html

40. Police arrest main accused in Uttarkashi rape and murder case. The Pioneer. 2018 Aug 25.

41. Times News Network. Home-alone 63-yr-old woman assaulted, robbed [Internet]. Timesofindia.indiatimes.com 2017 Oct 28 [cited 2020 Jun 8]. Available from: https://timesofindia.indiatimes.com/city/ mangaluru/home-alone-63-yr-old-woman-assaulted-robbed/ articleshow/61279294.cms

42. Siddiqui I. 11 of "religious" family found dead at home. Telegraphindia.com. 2018 Jul 2 [cited 2020 Jun 8]. Available from: https://www.telegraphindia.com/india/11-of-39-religious-39-familyfound-dead-at-home/cid/1349787

43. Times News Network. Police at a loss to keep track of militants [Internet]. Timesofindia.indiatimes.com. 2017 Jul 8 [cited 2020 Jun 8]. Available from: https://timesofindia.indiatimes.com/city/coimbatore/ police-at-a-loss-to-keep-track-of-militants/articleshow/ 59497533.cms

44. Sharma A. Cities of the Poor: A view on Urban Poverty in India [Internet]. Timesofindia.indiatimes.com. 2019 Nov 21 [cited 2020 Jun 7]. Available from: https://timesofindia.indiatimes.com/blogs/in-thename-of-development/cities-of-the-poor-a-view-on-urban-povertyin-india/

45. Aditi R. Rohingyas isolated at Kelambakam. Timesofindia.indiatimes.com. 2018 Dec 13[cited 2020 Jun 5]. Available from: https://timesofindia.indiatimes.com/city/chennai/rohingyasisolated-at-kelambakam/articleshow/67068172.cms

46. Editorial. Why migrant workers are seen as dispensable. Telegraphindia.com. 2018 Oct 19 [cited 2020 Aug 7]. Available from: https://www.telegraphindia.com/opinion/why-migrant-workers-areseen-as-dispensable/cid/1671407

47. Kashmiri Pandits demand homeland, Art 370 repeal. Dailypioneer.com. 2017 Aug 28 [cited 2020 Jun 8]. Available from: https://www.dailypioneer.com/2017/india/kashmiri-panditsdemand-homeland-art-370-repeal.html

48. Murshid N. Assam and the foreigner within: Illegal Bangladeshis or Bengali Muslims? Asian Surv. 2016 May;56(3):581-604.

49. Poop cuffs fails to raise stink. The Telegraph. 2017 Oct 23.

50. Sinha M. Toilets few, threat of fines fails to stop open defecation. The Times of India. 2018 Dec 1[cited 2020 Jun 5]. Available from: https:// timesofindia.indiatimes.com/city/noida/toilets-few-threat-of-finesfails-to-stop-open-defecation/articleshow/66889312.cms

51. McKay L, Macintyre S, Ellaway A. Migration and health: A review of the international literature. Glasgow: MRC Social and Public Health Sciences Unit, University of Glasgow;2003 Jan 12[cited 2020 Jun 5]. Available from: file:///D:/Admin/Downloads/ migrationandhealthreview.pdf

52. London School of Hygiene and Tropical Medicine. SWiFT Evaluation Evidence for Safe Migration. The occupational health and safety of migrant workers in Odisha, India. London:LSHTM; 2018 Dec 3[cited
2020 Jun 9]. Available from: https://www.Ishtm.ac.uk/files/swift-indiabrief-no.3-occupational-health-and-safety-dec18.pdf

53. Hameed SS, Kutty VR, Vijayakumar K, Kamalasanan A. Migration status and prevalence of chronic diseases in Kerala State, India. Int J Chronic Dis. 2013;4(23):23-7. Doi: 10.1155/2013/431818.

54. Ravindranath D, Trani JF, Lannotti L. Nutrition among children of migrant construction workers in Ahmedabad, India. Int J Equity Health. 2019 Sep 17;18(1):143.

55. Gentzkow M, Shapiro JM. Media bias and reputation. Cambridge MA: National Bureau of Economic Research; 2005 Sep [cited 2020 Jun 9]. (NBER Working Paper Series). Available from: https://core.ac.uk/ download/pdf/6894218.pdf

56. Migration and access to maternal healthcare: determinants of adequate antenatal care and institutional delivery among socioeconomically disadvantaged migrants in Delhi, India. Trop Med Int Health. 2013 Oct;18(10):1202-10.

57. Lalwani K. Story from Kashmiri Pandit's diary brought to screen [Internet]. Timesofindia.indiatimes.com. 2018 Jul 9 [cited 2020 Jun 8]. Available from: https://timesofindia.indiatimes.com/city/lucknow/ story-from-kashmiri-pandits-diary-brought-to-screen/articleshow/ 64912531.cms

58. PTI. Separate homeland demand gets right wing backing. Timesofindia.indiatimes.com. 2017 Jan 21 [cited 2020 Jun 8]. Available from: https://timesofindia.indiatimes.com/city/jammu/separatehomeland-demand-for-pandits-gets-right-wing-backing/articleshow/ 56693695.cms

59. Kapilashrami A, Issac A, Sharma J, Wickramage K, John E, Ravindranath $D$, et al. Neglect of low-income migrants in covid-19 response. BMJ. 2020 [cited 2020 Aug 7]. Available from: https://blogs.bmj.com/bmj/ 2020/05/29/neglect-of-low-income-migrants-in- covid-19-response/

60. Lakoff G, Ferguson S. The framing of immigration. The Rockridge Institute; 2006 [cited 2020 Jun 9]. Available from: https:// people.ucsc.edu/ nuclear/econ1/hotnews/framingimmigration.html

61. Anderson B. Us and them? 1st ed. New York: Oxford University Press; 2013.

62. Berk M, Schur C, Chavez L, Frankel M. Health care use among undocumented Latino immigrants. Health Aff (Millwood). 2000;19(4):5164.

63. Fassin D. The humanitarian politics of testimony. Cultural Anthropol. 2008;23(3):531-58.

64. Willen S. Birthing "invisible" children: State power, NGO activism, and reproductive health among undocumented migrant workers in Tel Aviv, Israel. J Middle East Women's Stud. 2005 Spring;1(2):55-8.

65. Hall S. The spectacle of the "Other", In: Hall S, ed. Representation: Cultural representations and signifying practices. London: Sage in association with the Open University; 1997.

66. Haynes A, Breen M, Devereux E. Smuggling Zebras far Lunch: Media framing of asylum seekers in the Irish print media. Études Irl. 2005;30(1):109-30.

67. Cottle S. Ethnic minorities and the media - Changing cultural boundaries. 1st ed. Philadelphia: Open University Press; $2000.2 \mathrm{p}$

68. Abdou C, Dunkel Schetter C, Campos B, Hilmert C, Dominguez T, Hobel $C$, et al. Communalism predicts prenatal affect, stress, and physiology better than ethnicity and socioeconomic status. Cultur Divers Ethnic Minor Psychol. 2010 Jul;16(3):395-403.

69. Forrest J, Burgess $M$, Mclntyre P. Factors influencing vaccination uptake:Workshop report. Commun Dis Intell. 2000 Feb; 24(3):51-3.

70. Spoonley PP, Butcher A. Reporting superdiversity. The mass media and immigration in New Zealand. J Intercult Stud. 2009 Nov 1;30(4):355-72.

71. Dunaway J, Branton RP, Abrajano MA. Agenda setting, public opinion, and the issue of immigration reform. Soc Sci Q. 2010;91(2):359-78.

\section{IJME is indexed on Pubmed, Scopus \& TPI.}

Articles from IJME, as also from the journal's previous titles Medical Ethics (1993-5),

and Issues in Medical Ethics (1996-2003) are indexed on Pubmed. 